\title{
Роман ГЕНЕГА
}

кандидат історичних наук, доцент кафедри історичного краєзнавства, Львівський національний університет ім. І.Франка

(Львів, Україна), r_genega@yahoo.com

ORCID: https://orcid.org/0000-0002-0346-405X

\section{Ірина ПАНЧУК}

докторка філософських наук, доцентка,

професорка кафедри філософії,

Рівненський державний гуманітарний університет

(Рівне, Україна), irinapanchuk21@gmail.com

ORCID: https://orcid.org/0000-0001-6301-4280

\section{«Сільське в міському»: аграрний сектор Львова та його внесок у повоєнну економіку міста}

DOI: https://doi.org/10.15407/!!! УДК: 908(477.83-25-21/-22)《194/195»

\begin{abstract}
Анотація. Мета дослідження - висвітлити особливий феномен повоєнного Львова, що полягав у взаємодії міста й села в межах міського простору. Сільські та міські практики справляли серйозний вплив на щоденне життя, змінювали харчування та етнічний колорит міста. Використано загальнонаукові методи - причинно-наслідковий, порівняльний, системного аналізу та ін. Наукова новизна. Уперше висвітлено діяльність сільськогосподарських підприємств, які активно використовували угіддя в межах міста. Окремим аспектом проаналізовано продукцію місцевих харчових підприємств, визначено їі популярність серед населення та встановлено рівень забезпечення містян продуктами. Акцентовано увагу на методах збереження продовольства за умов відсутності холодильного обладнання. Доведено, що аграрні експерименти в місті не були правилом, а радше винятком, зумовленим повоєнною розрухою. У результаті співпраці «міста» й «села»у Львові витворилося двояке соціальне середовище, зі своєрідними впливами на повоєнне місто. Висновки. У перші роки по війні традиційне господарство Львова співіснувало в одному просторі зі сільськими практиками, які проявлялися в культивуванні сільськогосподарських артілей (колгоспів), підсобних та індивідуальних господарств. Система зайнятості у сільському господарстві корелювала з партійною політикою репрезентації класовості в усіх сферах міського життя. Підсобні господарства, артілі та відгодівельні комплекси, організовані в умовах харчового дефіциту як один з елементів повоєнного виживання, були нетиповим явищем повоєнного міста. Попри невеликі обсяги львівського аграрного сектору його внесок у загальноміську фінансову систему був відчутним. Серед місцевої харчової продукції, виготовленої на базі сировини міських господарств, особливою популярністю користувалися варені ковбаси. Молочні товари займали незначний відсоток серед загального обсягу споживання молока в місті. Розводячи худобу, вирощуючи овочі та фрукти, львів'яни не лише забезпечували собі додатковий раціон, але й формували своєрідне соціальне середовище повоєнного Львова, яке відрізнялося від типових урбанізаційних процесів інших міст.
\end{abstract}

Ключові слова: Львів, артіль, колгосп, підсобне господарство, продовольча продукція. 
Посилена урбанізація практично не залишила нам візуальних згадок про «село в місті» - специфічне середовище, притаманне повоєнному Львову. Усі придатні для обробітку земельні ділянки тепер забудовані, лише де-не-де на них збереглися залишки колишніх колгоспних споруд як нагадування, що впродовж 1944-1953 рр. частина містян була задіяна у сільському господарстві. Невеликі земельні угіддя, які в межах міста ділили між собою компактні сільськогосподарські артілі-колгоспи та підсобні господарства львівських підприємств і мешканців, сформували своєрідний біполярний ландшафт «міста» й «села», актуальний тут до кінця І950-х рр. Містяни спокійно співіснували з худобою, утримання та забій котрої часто відбувалися у житлових кварталах. Тож Львів перших повоєнних років подеколи нагадував великий сільськогосподарський центр зі своїми правилами й управлінням. Продукція місцевих артілей після відповідної переробки потрапляла на полиці крамниць, суттєво покращуючи раціон львів'ян. Це був широкий асортимент м’ясних виробів і напівфабрикатів, молочних продуктів, яйця. Своєрідний симбіоз сільського та міського став вимушеною необхідністю, спровокованою повоєнним лихоліттям.

Взаємовідносини міста й села, попри певну дослідницьку перспективу, усе ж мало відображено в науковій літературі. Більшість дослідників міської історії, зосереджуючи увагу на урбаністичних моментах, водночас залишали поза увагою цілу низку сільських особливостей, якими жило повоєнне місто. Серед ключових розробок, присвячених цій проблематиці, слід виокремити низку колективних праць з історії Львова, котрі побачили світ як у часи СРСР, так і в період незалежності України. Попри певну тенденційність радянської історіографії у викладі та інтерпретації матеріалу, видання добре ілюструють дух епохи, а в окремих випадках слугують джерелом додаткових відомостей ${ }^{\mathrm{I}}$. Значно більш інформативним дослідженням, побудованим на раніше недоступних джерелах і літературі, стала кількатомна історії міста, підготовлена Інститутом українознавства ім. І.Крип'якевича НАН України. Третій том безпосередньо охоплює досліджуваний період, слугуючи доброю основою для подальших студій львовознавців ${ }^{2}$. Наступну групу історіографії становлять довідкові видання, які дозволяють викристалізувати досліджувану проблематику, показати ії в комплексі, на тлі тодішньої добиз. Важливим елементом довідкових праць виступає дуже концентрований, насичений виклад матеріалу, що дозволяє дослідникові практично повністю відтворити деталі тієї чи іншої події, явища. Водночас інформація, яка стосується аграрної складової Львова, доволі розрізнена та несистематизована. Беручи за основу наявну джерельну базу (архівні матеріали, пресу), нижче спробуємо проаналізувати й реконструювати львівське поєднання «міста» та «села» на тлі формування нових соціальних відносин. Окремим аспектом дослідження стане аналіз продукції, виготовленої зі сировини місцевих сільгоспартілей і підсобних господарств.

Попри свою, здавалося б, урбаністичну довершеність, Львів 1944-1945 pp. тісно поєднував міські та сільські традиції. Для кращої комунікації між міською владою й виробниками сільськогосподарської продукції поряд з іншими адміністративними районами навіть було утворено львівський сільський район, що опікувався

\footnotetext{
1 Львов: Краткий справочник / Б.К.Дудыкевич, И.П.Крипякевич, Г.П.Пинчук и др. - Л., 1946; Історія Львова: Короткий нарис / Під ред. Г.Ю.Гербільського. - Л., 1956; Історія Львова / Під ред. В.В.Секретарюка. - К., 1984.

2 Історія Львова: У 3 т. - Т.3: Листопад 1918 - поч. XXI ст. / За ред. Я.Ісаєвича. - Л., 2007.

3 Ініхов Г.С., Сперансвкий В.Г., Писарєв Н.С., Сиревич А.В., Бакзевич Д.Д. Товарознавство харчових продуктів / Пер. з рос. - К., 1954; Львів: Довідник / Під ред. М.Гресь. - Л., 1955; Товарный словарь / Под ред. И.А.Пугачёва. - Т.V: Лента - Мячи спортивные. - Москва, 1958; Гиль С.А., Шаферштейн С.Я. Питательные смеси для детей грудного возраста - К., 1952; Кисельова В.Б. Дитяча кухня: Книга для матерів про приготовляння їжі дітям / Під ред. доц. В.С.Вайль. - К., 1955.
} 
всіма вільними міськими землями сільгосппризначення (станом на листопад 1944 р. в місті нараховувалося 977г га орної землі, 3800 га природних лук), які розподілялися між колективними господарствами та городами для робітників і службовців (І389 га) ${ }^{4}$. Район мав усі атрибути, притаманні іншим районам міста - раду депутатів трудящих (вул. Радянська, 6; тепер В.Винниченка), нарсуд, що розміщувався на вул. I Травня, ІІ (нині просп. Свободи) стала бути гострою, адміністрацію ліквідували.

Надлишок вільних земель у Львові утворився внаслідок конфіскації приватних наділів, які й стали основою перших колективних господарств. Місто з околицями мало три сільськогосподарських артілі - ім. Й.Сталіна, ім. М.Хрущова, організовані в лютому 1945 р., та ім. І-го Травня, яка функціонувала з вересня I944 р. ${ }^{6}$ Це були чи не найперші повоєнні колгоспи не лише Львова, але й Львівщини.

У березні 1945 р. Львівський міськвиконком ініціював створення довкола міста «овочево-картопляної бази», що передбачало розширення парників у міських колективних господарствах. Використовували як капітальні теплиці, так і прості парникові рами. Це мало значно поліпшити забезпечення Львова овочами7. Серед трьох міських колгоспів-артілей провідну роль відігравало городнє господарство ім. І-го Травня. Воно було чи не найбільш «львівським», адже володіло значною частиною сільгоспугідь саме в межах міста, та дещо меншими наділами на околицях - у Брюховичах ${ }^{8}$ На початку роботи артіль розпоряджалася 72 га орної землі та 22 теплицями із загальною стелажною площею I5оо м². Згодом до ії складу включили нерентабельні підсобні господарства Львова9 . Артіль складалася з го бригад, які в основному займалися вирощуванням тепличної та грядкової городини (зеленої цибулі, шпинату, салату, петрушки, редиски, моркви, буряків, помідорів, цвітної капусти). Окрім того, господарство мало свиноферму, а також відгодівельне підприємство для великої рогатої худоби й пасіку⿰氵丶万 працівників цих артілей ${ }^{\text {II }}$.

Досвід роботи в умовах конкуренції, висока якість продукції дозволили артілі вже з перших днів демонструвати високі виробничі досягнення, хоча сама організація роботи відбувалася на основі нових для Західної України традицій зі впровадженням «соціалістичних змагань» та оплатою праці у вигляді трудоднів. У середньому працівник артілі міг заробити за місяць 32 трудодні (8оo руб.; г трудодень = 25 руб.), а при перевиконанні норми навіть 42 (II25 руб.; г трудодень $=26$ руб. 78 коп. $)^{12}$. Господарські й фінансові успіхи артілі в 1948 р. збільшили грошове вираження трудоднів до 3І руб. 56 коп. Також для додаткового заохочення адміністрація артілі за кожен трудодень надавала працівникам ще 4 кг картоплі та овочів. Існували й покарання за погану роботу, коли з бригади могли зняти до го\% трудоднів ${ }^{13}$. Гроші за них нараховували переважно в кінці кварталу, тож працівникам потрібно було заздалегідь планувати свій бюджет. Артіль мала дві «фірмові» крамниці в місті, де торгували щавлем, редискою, салатом. А, наприклад, у травні - червні 1946 р. у цих магазинах

\footnotetext{
4 Державний архів Львівської обл. (далі - ДАЛО). - Ф.Р-100. - Оп.1. - Спр.1. - Арк.118, 120.

Львов: Краткий справочник. - С.82.

6 ДАЛО. - Ф.Р-100. - Оп.1. - Спр.12. - Арк.67.

Там само. - Ф.Р-6. - Оп.2. - Спр.79. - Арк.136-136 зв.

8 Вільна Україна (Львів). - 1945. - 10 червня.

9 Львовская правда. - 1947. - 25 марта.

${ }^{10}$ Там же. - 1948. - 1 февраля.

${ }^{11}$ Вільна Україна. - 1945. - 10 червня.

12 Там само.

13 Львовская правда. - 1948. - 1 февраля.
} 
продавали гриби. Натомість ранні огірки можна було придбати вже на початку вес-

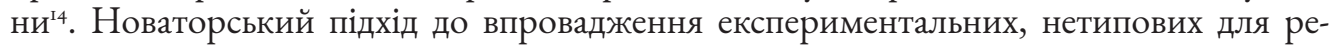
гіону культур - кавунів, динь, суниць, мандаринів ${ }^{15}$, навіть чаю сорту «Ява», посіви якого у травні 1948 р. на площі о,25 га культивував ланковий В.Гутай ${ }^{16}$, - зумовили фінансові успіхи артілі. Уже на початку 1946 р. господарство ім. І-го Травня стало першим мільйонером Львівської обл.

Голова артілі Задесенець керував уміло, розумно розпоряджався трудовими ресурсами. Працівники не були прив'язані до жодної виробничої ланки й могли вільно перекидатися на різні роботи, відповідно до потреб господарства. Такий підхід до роботи виходив за межі розуміння міського партійного керівництва, за що Задесенця постійно критикували. У підсумку він був усунений із посади, а на його місце призначили Д.Олинця ${ }^{17}$. Зміна керівництва разом із плинністю досвідчених кадрів негативно вплинули на виробничі можливості господарства та спричинила фінансові втрати. Підприємство-мільйонер у г946-г948 рр. із річним доходом г 884750 руб.' у 1950 р. вже не могло виконувати своїх фінансових зобов'язань перед містом. На засіданні фінансово-бюджетної комісії міськради депутатів трудящих 9 червня 1950 р. зазначалося, що Шевченківський р-н Львова недоотримав від артілі ім. г-го Травня 63 тис. руб. податків. Вона також мала недоїмку (недоплату) й за попередній 1949 р. на суму 47 тис. руб. ${ }^{19}$ Погіршення показників господарства було пов’язане з новими підходами до роботи, упроваджуваними владою. Та попри це працівники намагалися вдосконалювати свої можливості з вирощування городини, розширення асортименту продукції. Станом на січень г95і р. в оранжереях на вул. Пекарській, за якими доглядала ланкова І.Зелінська, зацвіли кущі білого бузку - цей цвіт користувався підвищеним попитом серед львів'ян ${ }^{20}$. Із березня 195I р. господарство пропонувало мешканцям свіжі помідори. Селекція розсади квітів і декоративних кущів, культивування ранніх овочів приносили добрі прибутки.

Ще одним характерним явищем повоєнного Львова було підсобне господарство - невеликий земельний наділ (у декілька сотих гектара), наданий в індивідуальне чи колективне користування львів'янам і міським організаціям. У багатьох випадках земельні ділянки межували з житловою забудовою й на перших порах були навіть у центральній частині міста (вул. М.Горького, з; тепер В.Гнатюка). Специфіка розвитку підсобних господарств передбачала не лише вирощування різноманітних культур, але й розведення худоби. Очевидець пригадував: «Допомагало підсобне господарство невеличкий город, що дозволяв виживати. Згодом, живучи на Збоїщах, трохи дальше від центу, ми тримали порося і було легше»².

Усі підсобні господарства Львова патронував міськвиконком, визначаючи розміри земельних ділянок, чисельність поголів'я худоби, кількість фруктових дерев, податки тощо. У місті існувало декілька форм підсобного господарювання - відомче, службово-індивідуальне, приватне, яке в обмеженому вигляді зберігалося до початку I950-х рр. Для координації дій підсобних господарств при виконкомі створили окремий сільськогосподарський сектор.

\footnotetext{
${ }_{14}$ Вільна Україна. - 1946. - 19 квітня; 2 червня.

15 Львовская правда. - 1947. - 25 марта.

${ }_{16}^{16}$ Вільна Україна. - 1948. - 29 травня.

17 Львовская правда. - 1950. - 27 декабря.

${ }_{18}$ Там же. - 1948. - 1 февраля.

19 ДАЛО. - Ф.Р-6. - Оп.2. - Спр.404. - Арк.62.

${ }_{20}$ Вільна Україна. - 1951. - 9 січня.

${ }^{21}$ Інтерв’ю з Євгеном Ратушним, 1932 р. н., записане у Львові 22 вересня 2015 р. (особистий архів автора).
} 
Вільної міської землі, призначеної для підсобних господарств, було 502 га, з яких уже 279,50 га роздано підприємствам і громадянам. Попри те, бажаючих отримати в користування ділянки серед нових містян було ще досить багато. На середину 1945 р. в міськраді налічувалося 26 І23 заяви, автори яких очікували на позитивне вирішення $^{22}$. Ще 116 га сільгоспземлі станом на квітень 1947 р. перебували у власності корінних мешканців. Ці ділянки розташовувалися на околицях міста в районах Старого й Нового Знесіння, Голоска Малого, Клепарова. У середньому львів'яни володіли земельними наділами від о,25 га до 7 га. Але невдовзі рішенням міської ради від II квітня 1947 р. було вирішено залишити в руках приватних власників для господарювання не більше о,І5 га $\mathrm{a}^{23}$. Реквізовані надлишки наступного року розподілили серед робітників і службовців Львова. Загалом у березні 1948 р. ділянки отримали ще 24 тис. осіб ${ }^{24}$. Кінець індивідуального, фактично приватного володіння землею (поза межами колективів підприємств та установ) настав у серпні г95і р. Саме тоді міськрада ухвалила постанову про вилучення з індивідуального користування всіх городніх наділів і польових земель після збору врожаю восени. Виняток становили лише присадибні ділянки з садами. На середину 1952 р. у Львові нараховувалося 75 тис. плодових дерев, більшість з яких перебували у приватному секторі, інша частина - у підсобних господарствах підприємств ${ }^{25}$. Вилучені землі мали передати офіцерам армії, інвалідам війни, родинам загиблих військовиків, матерям-героїням, пенсіонерам ${ }^{26}$.

Розвиток відомчих підсобних господарств міська влада стимулювала командно-адміністративними методами планової економіки. Згідно з рішеннями облвиконкому та обкому КП(б)У, підсобні господарства міськради, міліції, тресту їдалень та ресторанів, кондитерських фабрик, університету, політехнічного інституту, інших навчальних закладів і міських установ лише впродовж 1945 р. повинні були виростити 26 тис. голів птиці ${ }^{27}$. Від обсягів вирощеного залежала робота підприємств громадського харчування. Під час голоду 1947 р. виконком міськради зобов’язав відповідні установи Львова, включно з ресторанами, не використовувати при приготуванні їжі верхні частини картопляних бульб, залишаючи їх як посівний фонд для міських підсобних господарств. Усі витрати, пов'язані з обрізанням і належним зберіганням цих обрізків картоплі, авансом перекладалися на прибутки від майбутнього врожаю28. Подібна практика збереглася й 1948 р., коли харчові організації міста мали заготовити гоо т картопляного посівного матеріалу ${ }^{29}$. Зрештою це стане нормою для Львова навіть у наступні роки.

Добровільно-примусовий підхід до створення підсобних господарств при установах та організаціях не міг забезпечити належний рівень їх функціонування. Рентабельними стали лише потужні міські підприємства з фаховим управлінням, зокрема трест саночистки або міліціяз ${ }^{\circ}$. Натомість підсобне господарство міської ради, попри постійний контроль із боку адміністрації, перебувало на межі колапсу. У 1946 р. внаслідок неналежного догляду тут загинули посіви цибулі, моркви, огірків, буряків, картоплі. Худоба не доглядалася, надої молока мізерні ${ }^{31}$. Керівник

\footnotetext{
22 ДАЛО. - Ф.Р-6. - Оп.2. - Спр.79. - Арк.143.

23 Там само. - Спр.251. - Арк.8-10.

${ }_{24}$ Там само. - Спр.289. - Арк.107.

${ }_{25}$ Там само. - Спр.523. - Арк.45.

${ }_{26}$ Там само. - Спр.439. - Арк.91-93.

${ }_{27}$ Там само. - Спр.67а. - Арк.37-38.

${ }_{28}$ Там само. - Спр.228. - Арк.69.

29 Там само. - Спр.250. - Арк.12-13.

${ }_{30}$ Там само. - Спр.79. - Арк.141.

${ }^{31}$ Там само. - Спр.204. - Арк.340-340 зв.
} 
господарства Рехман вирішив заручитися підтримкою можновладців та організував розподіл молочних поросят (віком до 3 міс.) серед працівників міськкому КП(б)У й виконкому Львівської ради. Тварин пропонували лише керівному складу. Їх отримали 16 членів виконкому, 4 голів виконкомів районних у місті рад, го функціонерів міськкому КП(б)У і з особи з підсобного господарства. Поросята продавалися за символічною ціною у живій вазі ${ }^{32}$. I все ж у липні 1946 р. Рехмана з посади усунули, а на його місце був призначений О.Жуковський.

Байдуже ставлення керівників і працівників підсобних господарств до результатів праці в багатьох випадках призводило до використання сільгоспземель не за призначенням. У кращому випадку їх здавали в оренду. Тож у березні 1949 р. міськвиконком ухвалив рішення про черговий перерозподіл I88 га таких земель між робітниками і службовцями Львова для індивідуальних городів та садів. Ділянки надавались у безстрокове користування, за умови безперервної праці на підприємстві чи в установі впродовж п’яти років після отримання наділу. Землі, надані в користування, повинні бути освоєні не пізніше з років від моменту отримання. Якщо робітник виїжджав зі Львова, він втрачав право на ділянкуз3.

Перерозподіл міських сільськогосподарських земель не вирішив проблеми рентабельності та не сприяв ладу у землекористуванні. На середину г95о р. у Львові у приватному користуванні перебувало ще понад гоо га фондових міських земель. Розмір ділянок у багатьох випадках і надалі перевищував установлені виконкомом о,І5 га. Земельна рента за понаднормові сотки, звичайно, не сплачувалася. Не нехтували підробітком від передачі землі в оренду й державні паровозоремонтний і нафтопереробний заводи, нафтобаза, військторг, політехнічний інститут та ін. Фактично частина наданих цим підприємствам, установам земель передавалася в оренду приватним особам, решта використовувалася для наділів працівникам ${ }^{34}$.

Не всі мешканці Львова були задоволені аграрними успіхами окремих громадян. Для прикладу, мешканці будинку №8 на вул. О.Матросова (тепер Кастелівка) неодноразово скаржилися в міськраду на своїх сусідів і двірників, котрі використовували пустирі біля будинку під городи, вимагаючи створити там спортивний або дитячий майданчик ${ }^{35}$. Подекуди міськрада, не спромігшись належно організувати розподіл вільних сільгоспземель, втручалася вже на стадії дозрівання врожаю, реквізовуючи їх та передаючи іншим власникам. Зокрема в липні г95о р. рішенням виконкому кінно-поштовій станції обласного управління зв'язку було передано 2,5 га посівів жита в урочищі Замарстинів - як такі, що були самовільно засіяними львів'янами ${ }^{36}$.

Окрім згаданих вище випадків, неналежно господарювали й у тресті ресторанів та їдалень, у 2-й міській лікарні, у навчально-дослідному господарстві сільгосптехнікуму, де взимку І95і р. довели худобу (коней, корів, свиней) до крайнього виснаження $^{37}$. Вирощували свиней та активно обмінювали племінне поголів'я підсобні господарства Львівгазу і психіатричної лікарні ${ }^{38}$. Однак попри збільшення числа худоби в підсобних господарствах міста провали в постачанні м'яса траплялися доволі часто. Скажімо, у першому кварталі І95і р. міські райхарчторги не змогли забезпечити

\footnotetext{
32 Там само. - Арк.204-204 зв.

33 Там само. - Спр.316. - Арк.115-117.

${ }_{34}$ Там само. - Спр.363. - Арк.13.

35 Там само. - Спр.371. - Арк.48-49.

${ }_{36}$ Там само. - Спр.375. - Арк.41.

${ }_{37}$ Там само. - Спр.413. - Арк.22.

${ }_{38}$ Там само. - Спр.382. - Арк.101.
} 
м’ясною продукцією навіть установи закритого типу (дитячі будинки, садки тощо), не кажучи вже про торгівельну мережуз3.

Дещо краще доглядали за тваринами у приватних господарствах. Згідно зі звітом Львівської міської ради, на І січня 1947 р. населення утримувало г34і голову великої рогатої худоби, І867 свиней, І76 овець, 574 кози, І592 коня. Більшість із переліченого (за винятком коней) припадало на одноосібників, робітників та службовців. Порівняно 31946 р. відбулося зменшення поголів'я на 20\%, що було пов'язано з виїздом польського населення ${ }^{40}$. Власники тварин сплачували місту податок у розмірі 600 руб. за голову (станом на г950 р.), який суттєво применшував ініціативу подальшого збільшення поголів'я. Фактично львів'янин, котрий утримував корову і платив за неї такий податок, змушений був шукати ринки збуту для тваринної продукції як компенсацію не завжди вмотивованих витрат ${ }^{41}$. Інколи ситуація виходила за межі здорового глузду. Так, у 1945 р. у багатоквартирному будинку на вул. Вроновських, I4 В (тепер Ф.Колесси) капітан Лазарєв у власній квартирі №8 організував відгодівлю свині та курей ${ }^{42}$.

Розведення худоби мало певні незручності, пов'язані не лише з утриманням, але й перегоном та забоєм. Із середини I946 р. рішенням міськвиконкому було заборонено подвірний забій у межах міста - це належало робити лише на м'ясокомбінатах і з дозволу ветеринара. Контролювали виконання постанови ветеринарна служба разом із міліцією43. Основний забійний пункт Львова в 1944-1953 рр. розміщувався на території психіатричної лікарні. Його орендували м'ясокомбінат, облспоживспілка. Іншим організаціям провадити самовільний забій заборонялося ${ }^{44}$. Дещо менший забійний пункт деякий час діяв на Левандівці (вул. Кознярівка, І27) під егідою крохмально-патокової артілі, але його було закрито в лютому 1948 p. ${ }^{45}$ I все ж несанкціонований забій худоби в межах міста існував і надалі, перейшовши «в тінь» ${ }^{46}$. У грудні I949 р. виконком констатував, що у Львові проводиться неконтрольований подвірний забій як громадянами приватного сектору, так і державними підприємствами та установами ${ }^{47}$.

Поряд з артілями та підсобними господарствами у Львові діяли два потужних відгодівельних комплекси - птахо- та свинокомбінати. Птахокомбінат, організований 1952 р., розміщувався на вул. Нова Різня, 46 (тепер Промислова), по сусідству з м'ясокомбінатом ${ }^{48}$. Принцип роботи відрізнявся від сучасних птахофабрик. Молодняк живої птиці (гуси, качки, індики, кури), а також кролів надходив на відгодівлю не лише з міста, але з усієї Західної України. Завданням працівників комбінату було довести вгодованість отриманої птиці та кролів до рівня вище середнього, після чого вони йшли на забій. Підприємство було частково механізованим (обладнання для общипування птиці й оббілування кролів), але відсоток ручної праці був ще значним (норма общипування для одного працівника становила 30 гусей за зміну). Оброблені тушки заморожувалися у холодильному цеху, після чого надходили до споживача ${ }^{49}$.

\footnotetext{
39 Там само. - Спр.437. - Арк.21.

${ }^{40}$ Там само. - Спр.224. - Арк.87.

${ }^{41}$ Там само. - Спр.397. - Арк.97.

${ }_{42}$ Там само. - Спр.195. - Арк.175.

${ }^{43}$ Там само. - Арк.99.

${ }_{44}$ Там само. - Спр.262. - Арк.14.

${ }^{45}$ Там само. - Спр.265. - Арк.132.

${ }^{46}$ Там само. - Спр.289. - Арк.109.

${ }_{47}$ Там само. - Спр.341. - Арк.68.

${ }^{48}$ Там само. - Спр.34а. - Арк.360.

49 Вільна Україна. - 1952. - 5 липня.
} 
Львівський свиновідгодівельний комбінат, організований наприкінці 1948 р. на базі земель колишніх підсобних господарств міських підприємств, складався з трьох відділень і восьми ділянок на околицях Львова. Комбінату належало 8 оо га земель, з яких 230 га засівали зерновими. Літом 1949 р. тут відгодовували г78о свиней і г2о голів великої рогатої худоби, були також вівці, птиця, пасіка ${ }^{50}$ Все це працювало на забезпечення міста продовольством. Свиней для відгодовування на комбінат привозили різного віку та ваги (від эо кг і вище). Тут їх доводили до певних вагових норм, після чого відправляли на м’ясокомбінат ${ }^{\text {s1 }}$.

Зіставну з відгодівельними комбінатами нішу в міській системі харчування займав харчовий комбінат, який розпочав роботу у січні 1953 р. та підпорядковувався Львівському облхарчпрому. Відтоді під його егідою працювали всі дрібні харчові підприємства міста. Комбінат також розпоряджався 50 га фруктових садів, у тому числі садом на вул. Замковій, і 25 га орних земель на вул. Пісковій. Директора підприємства призначав виконкомом. У планах випуску продукції були гірчиця, бурячки з хроном, томатні сік та пюре, сухі киселі, повидло, оцет, плодово-ягідні вина, натуральні соки, пиріжки. У майбутньому комбінат планував побудувати птахо- та кроликоферми ${ }^{52}$.

Сировину, отриману від колективних та деяких підсобних господарств, переробляли львівські харчові підприємства. Асортимент продукції формувався на основі державних зразків, за категоріями й нормами, установленими у СРСР. Базовими м'ясопереробними підприємствами Львова на той час були беконно-консервна фабрика та м’ясокомбінат. Перша розпочала свою роботу відразу ж після повернення радянської влади, і вже у серпні 1945 р. вийшла на показник г т ковбас за зміну фабрики була високої якості та користувалася підвищеним попитом серед споживачів. У квітні 1945 р. ковбасний цех підприємства завоював 3-тє місце на Всесоюзному соціалістичному змаганні «за оригінальність рецептури та якість ковбаси»54. Своя сировинна база - свиновідгодівельний пункт на вул. Б.Хмельницького, 223, поряд із постачанням м’яса від населення, забезпечувала безперебійну роботу фабрики 5 . Уже в лютому 1948 р. було освоєно випуск 6 нових видів ковбас обсягом 4 т за зміну, ще 2 види планували робити в майбутньому ${ }^{56}$. Асортимент фабрики постійно змінювався і включав також пельмені, котлети, сосиски, сардельки, кров'янку, паштети, холодець, м’ясні пиріжки, субпродуктові ковбаси III гатунку57. Львівський м'ясокомбінат розпочинав свою роботу доволі скромно, доля його продукції не перевищувала результати праці дрібних кустарних артілей. У серпні 1945 р. за зміну він давав 20 т м'яса й ковбас ${ }^{58}$. Але вже в лютому 1948 р. підприємство почало прийом у необмежених обсягах свиней, великої рогатої худоби, овець із метою створення запасів замороженого м'яса - як від державних, кооперативних установ, так і від населення 9 У квітні 1953 р. беконно-консервну фабрику та м'ясокомбінат було об'єднано в одне підприємство під назвою Львівський м’ясокомбінат ${ }^{60}$. Це суттєво збільшило асортимент, обсяги продукції. Окрім традиційних м’яса і ковбасних виробів тут освоїли

\footnotetext{
sо Львовская правда. - 1949. - 9 июля.

51 Там же. - 1953. - 15 декабря.

52 ДАЛО. - Ф.Р-6. - Оп.2. - Спр.526. - Арк.70-91.

53 Там само. - Ф.Р-100. - Оп.1. - Спр.3. - Арк.10.

${ }_{54}$ Вільна Україна. - 1945. - 10 червня.

55 ДАЛО. - Ф.Р-6. - Оп.2. - Спр.286. - Арк.23.

${ }_{56}$ Львовская правда. - 1948. - 12 февраля.

57 ДАЛО. - Ф.Р-6. - Оп.2. - Спр.276. - Арк.28-31.

58 Там само. - Ф.Р-100. - Оп.1. - Спр.3. - Арк.10.

59 Вільна Україна. - 1948. - 20 лютого.

${ }_{60}$ Львовская правда. - 1953. - 21 апреля.
} 
випуск напівфабрикатів: порційних (г25 г) делікатесних м’ясних відрізків, які постачалися в торгівельну мережу запакованими у целофан чи пергамент, пельменів, котлет, шашликів, м’ясних рагу, шніцелів та ін. Новинкою були й консерви в невеликих упаковках (печінкові, м’ясні паштети, смажене м'ясо), а також у з-літрових банках. Ковбасний цех подвоїв випуск продукції, причому планувалось освоїти фаршировані ковбаси та курячі сосиски. У цілому комбінат давав продукції на 300 тис. руб. щомісяця й разом з артіллю ім. І-го Травня став однією з небагатьох міських установ-мільйонерів $^{\text {б. }}$ Водночас, слід зауважити, що радянська система розподілу продуктів часто призводила до провалів у постачанні. Попри серйозну виробничу базу на львівських складах головм'ясторгу в 1953 р. можна було отримати не більше семи видів ковбаси. Важкодоступними для покупців залишалися копчені й напівкопчені вищого гатунку. Вагове ж м’ясо постачалось у мережу лише з тварин середньої та нижче середньої вгодованості й переважно одного виду (яловичина, свинина, рідше баранина) ${ }^{62}$.

Яку ж продукцію пропонували львівські м’ясопереробні підприємства? Першість за популярністю серед містян утримували варені ковбаси, що отримали назву від технології приготування (3-годинне копчення й варіння до готовності). Поділялися вони на гатунки: вищий («Столична», «Білоруська», «Докторська», «Любительська», «Теляча», «Куряча»), перший («Окрема», «Шинко-рублена», «Особлива»), другий («Чайна», «Яловича», «Закусочна»). Різниця полягала в основній сировині - м’ясо вищого, першого і другого гатунку з додаванням субпродуктів та соєвого борошна. Різновидом варених ковбас були сосиски. Вони були двох гатунків: вищого («Радянські», «Молочні», «Свинячі») та першого («Російські», «Яловичі», «Сирі», «Сардельки») ${ }^{63}$.

До вищого класу відносилися напівкопчені ковбаси. Технологія їх виготовлення була складнішою - ферментація м’яса тривала 20 діб, водночас обсяги виробництва та цінова політика робили їх доступними для більшості львів'ян. Ці ковбаси поділялися на вищий («Краківська», «Полтавська», «Київська», «Мисливські ковбаски», «Свиняча домашня»), перший («Українська», «Мінська», «Бараняча») та другий («Польська», «Семипалатинська») гатунки. Ціна «Української» станом на грудень 1953 р., зокрема, складала І9 руб./кг ${ }^{64}$.

На найнижчому щаблі ковбасної ієрархії перебували вироби з субпродуктів, які також знаходили свого покупця. У торгівлю вони надходили як «ліверна ковбаса» та були трьох гатунків: вищого («Яєчна» - 33\% свинячої печінки, 25\% телятини, 39\% свинячої щоковини, борошно, молоко), першого («Копчена», «Звичайна») і третього (до складу входили легені, рубці, губи). Ліверну ковбасу другого гатунку у Львові не виробляли. У літній період через брак холодильного обладнання деяка м'ясна продукція була заборонена до реалізації, зокрема ковбаса варена третього гатунку, часниково-яловича з рослинними домішками, ліверна третього гатунку, кров'яна, холодець, паштети, запіканки, кров’яні білково-рослинні та м’ясо-рослинні котлети ${ }^{65}$. Проте заборони часто обходили або ігнорували. Так, на ринку «Теодора» серед продукції облспоживспілки неодноразово траплялися прострочені ковбаси, забраковані санітарним наглядом ${ }^{66}$.

\footnotetext{
${ }_{61}$ Там же. - 20 декабря.

${ }_{62}$ ДАЛО. - Ф.Р-6. - Оп.2. - Спр.598. - Арк.143, 151.

${ }^{63}$ Ініхов Г.С., Сперанський В.Г., Писарєв Н.С., Сиревич А.В., Бакзевич Д.Д. Товарознавство харчових продуктів. C.390-392.

${ }_{64}$ Львовская правда. - 1953. - 4 декабря.

${ }_{65}$ ДАЛО. - Ф.Р-6. - Оп.2. - Спр.67. - Арк.366.

${ }_{66}$ Там само. - Спр.233. - Арк.5-6.
} 
Ще одним важливим продуктом харчування, який постачався львівськими сільськогосподарськими артілями та підсобними господарствами, було молоко. Для забезпечення багатотисячного міста отриманої від місцевих господарств сировини було недостаньмо, тому довгий час відчувався дефіцит. Депутат міської ради Я.Галан стверджував, що в 1940-х рр. купити молоко у львівських державних магазинах було неможливо, хіба що на базарах, але там орудували перекупники, котрі розводили його водою67. I все ж продукована кількість молока дозволяла безперебійно працювати місцевим переробним підприємствам. До 7о\% отриманої сировини припадало на долю комбінату «Укрголовмолоко» (вул. Я.Головацького, 23), молококомбінату № (вул. Московська, 23; тепер Братів Міхновських) та молокозаводу №2, що працював на вул. Ярослава Мудрого, ІІ. Решта молочного ринку перебувала під впливом невеликих, часто кустарних підприємств, які займалися виготовленням морозива. Згідно з тодішніми стандартами, молоко в торгівельну мережу постачали розіллятим у пляшки ємністю г л, о,5 л, о,25 л, пастеризованим і жирністю не менше 3,2\% ${ }^{68}$. Пляшка закривалась алюмінієвою або картонною кришечкою, що містила інформацію про продукт, назву заводу, дату випуску та ГОСТ. Додаткові дані про жирність, кислотність, температуру зберігання можна було знайти в паспорті або в накладній, які додавалися до кожної партії товару. Молоко продавали й на розлив. До точок продажу його доправляли в металевих флягах-бідонах із гумовими або паперовими прокладками. На нього поширювалися такі ж стандарти, як і на пляшкове. Інші молочні продукти (сметана, сир) надходили в невеликих дерев'яних цеберках ${ }^{69}$. У дещо менших обсягах пропонували молоко з кавою та цукром (на гоо г молока жирністю 3,2\% - Іо\% цукру, 2,5 г натуральної або ячмінної кави), із цукром (5\%) та з шоколадом (г2\% цукру, 2,5 г какао-порошку). Молоко з добавками також пастеризувалося й відпускалося у пляшках місткістю о,5 л і о,25 то $^{70}$ Однак попри позірне товарне різноманіття придбати весь асортимент молочних продуктів у Львові в перші повоєнні роки було практично неможливо. Лише на середину г950-х рр. місцева продукція почала з'являтися в торговельній мережі. Львівський комбінат «Укрголовмолоко» навіть активно рекламував свою продукцію, пропонуючи пастеризоване й ацидофільне молоко, сметану, вершки, дієтичні жирні та знежирені вироби, кефір, сирки дитячі глазуровані, морозиво (пломбір, ескімо та ін.)ㄱ. Твердий сир у Львові попитом не користувався. У серпні 1953 р. міські склади були ним переповнені, позаяк реалізувати вдалося тільки $57 \%$ запасів цього продукту ${ }^{72}$.

Окремої уваги заслуговує дитяче молочне харчування. Для цих потреб надавалася найякісніша сировина з колективних міських та приміських господарств. У віданні міськвідділу охорони здоров’я перебувала центральна молочна кухня (вул. Пушкіна, 6г; тепер Генерала Чупринки), куди й постачалося молоко. Під іï контролем діяли 6 менших молочних кухонь, які працювали при дитячих консультаціях. Одна з найкращих молочних кухонь у 1945 р. функціонувала на вул. Чайковського, 22 $2^{73}$. У різний час центральна молочна кухня обслуговувала від 2 до 4 тис. дітей віком 3 міс. - 6 років. Основним ії завданням було виготовлення поживних харчових сумішей. Обмежений термін їх придатності спонукав до гіперболізованих заходів гігієни. Ситуація дещо покращилась у квітні І95I р., коли центральна молочна кухня

\footnotetext{
${ }_{67}$ Там само. - Спр.344. - Арк.62-63.

68 Львовская правда. - 1951. - 12 апреля.

${ }_{69}$ ДАЛО. - Ф.Р-6. - Оп.2. - Спр.290. - Арк.95.

70 Товарный словарь. - T.V. - C.758-764.

${ }^{71}$ Львів: Довідник. - С.386.

72 ДАЛО. - Ф.Р-6. - Оп.2. - Спр.584. - Арк.128.

${ }_{73}$ Львов: Краткий справочник. - С.76.
} 
придбала новинку - один із перших на той час електричних холодильників ціною I4 тис. руб. ${ }^{74}$ Відтоді якість дитячого харчування у Львові суттєво зросла.

Найбільш популярними серед батьків, згідно з рекомендаціями радянських педіатрів, уважалися круп'яні слизисті відвари (4-го-процентні, переважно з вівсяної, рисової та ячмінної круп, розведені водою або молоком із додаванням цукру, солі, сиру), які виготовлялися на центральній молочній кухні. Вони мали назви «КРС» (концентрований рисовий слиз), «ЯКС» (ячневий концентрований слиз), «КПС» (концентрований пшоняний слиз). За аналогічним принципом готувалися й борошняні відвари. Зберігатися така продукція могла лише півдоби у холодильнику. Серед молочних сумішей найактуальнішими вважалися номерні: №, №2, № 3 , № 4 . У перших трьох молоко розводилося водою в різних пропорціях і відпускалося як основа для приготування відварів, натомість №4 містила пряжене (кип'ячене) молоко з 5-процентним вмістом цукру. Також підприємство пропонувало молоко зі свіжим жовтком і цукром, жовтком та лимоном, морквяно-молочну суміш, ацидофільне, білкове, масло-борошняне, соєве молоко, кефір. Гострим дефіцитом уважалося пастеризоване або заморожене грудне молоко ${ }^{75}$. Також кухні виготовляли й відпускали висококалорійні обіди, кисломолочні продукти, молоко та суміші для хворих дітей $^{76}$. Для отримання харчування на молочній кухні породіллі, а також матері повинні були стояти на обліку в міських дитячих консультаціях.

За бажання в торговельній мережі Львова можна було придбати дитяче харчування й без реєстрації, щоправда воно було нижчого гатунку. Насамперед це суха суміш «Дитяче поживне борошно», яка містила пшеничне борошно, сухе молоко, цукор, яйця та вершкове масло. Її рекомендувалося розводити з молоком, бульйоном або водою у співвідношенні г : 3 і давати немовлятам. Ціна упаковки становила 3 руб. 16 коп. ${ }^{77}$ У розпорядженні матерів були також сушені відвари з рису, вівса, інших круп, які пропонувала повоєнна радянська харчова промисловість ${ }^{78}$.

Важливим елементом львівської молочної індустрії було виготовлення морозива. Залежно від складу інгредієнтів воно поділялося на вершкове, пломбір, молочне, фруктово-ягідне та ароматизоване. Розфасовували його у вафельні й паперові стаканчики, вафельні брикети. Вафельні або цукрові трубочки продавали на вагу у вигляді тортів, тістечок тощо. При виготовленні продукції використовувалися барвники та стабілізатори, зокрема харчовий крохмаль, желатин, аґар ${ }^{79}$. Львівське морозиво в перші повоєнні роки виробляли десятки місцевих підприємств. Найбільшими серед них були молококомбінат №ㄴ, холодокомбінат, артілі «Червоний мінеральщик», «Промкуст», ім. А.Мікояна та ін. Недосконалість, а в багатьох випадках і відсутність спеціального холодильного обладнання ставали причиною доволі низької якості ${ }^{80}$. Вагова продукція за декілька годин торгівлі повністю втрачала товарний вигляд, перетворюючись на молокоподібну рідину. У той час у Львові практично не було фасованого морозива, а для брикетованого не вистачало вафельних форм ${ }^{81}$. Однак навіть у такому вигляді ласощі знаходили свого покупця. У середньому за один літній

\footnotetext{
74 ДАЛО. - Ф.Р-6. - Оп.2. - Спр.424. - Арк.190.

${ }^{75}$ Гиль С.А., Шаферштейн С.Я. Питательные смеси для детей грудного возраста - С.15-51; Кисельова В.Б. Дитяча кухня: Книга для матерів про приготовляння їжі дітям. - С.35-45.

${ }^{76}$ Вільна Україна. - 1945. - 8 вересня.

77 Книга о вкусной и здоровой пище / Под ред. О.П.Молчанова, Д.И.Лобанова, М.О.Лифшица, Н.П.Цыпленкова. Москва, 1952. - С.334.

${ }^{78}$ Ініхов Г.С., Сперанський В.Г., Писарєв Н.С., Сиревич А.В., Бакзевич Д.Д. Товарознавство харчових продуктів. - С.625.

79 Товарный словарь. - T.V. - С.808-818.

${ }^{80}$ ДАЛО. - Ф.Р-6. - Оп.2. - Спр.237. - Арк.9.

${ }^{81}$ Там само. - Спр.271. - Арк.180-180 зв.
} 
місяць (липень 1948 р.) містяни спожили 98 т морозива ${ }^{82}$. Попит був величезним. Виробленої міськими підприємствами продукції вистачало на I-2 год. активної торгівлі. Задоволення такого попиту неодноразово ставало темою розгляду на засіданнях виконкому ${ }^{83}$. У 1949 р. якість львівського морозива продовжувала залишатися неналежною. Проблема висвітлювалася навіть в обласній партійній пресі. Так, кореспондент П.Животенко у фейлетоні «Комбінатори з холодокомбінату» писав: «Продавщиця відпускає перехожим щось загорнуте в папірці, на яких на полярній крижині кудись мандрує полярний ведмідь. I собі за карбованець купую морозиво. Обережно проковтую шматочок, другий. Відчуття підфарбованого снігу [...] це сніговисько ми звемо “фруктове-примусове” ${ }^{84}$. Ще однією проблемою була відсутність етикеток. Основні виробники львівського морозива - молочний і холодокомбінати - до кінця г95г р., ігноруючи заборону Державної молочної інспекції, продовжували випускати продукцію без них ${ }^{85}$. Це унеможливлювало виявлення «бракоробів».

Якість морозива підвищилася після того, як на підприємствах з'явилося нове холодильне обладнання. У серпні 1953 р. Львівський холодокомбінат міг уже похвалитися об’ємною «гартувальною камерою» 3 температурою $-24^{\circ} \mathrm{C}$, в якій морозиво доводилося до потрібної кондиції, утворюючи гомогенну масу без шматочків льоду. Щодня підприємство випускало 4 т продукції - це було більше, ніж усі виробники в 1945-1946 рр. Асортимент також суттєво розширився. Пломбір та ескімо виготовлялися двох гатунків. Незмінною популярністю серед львів'ян користувалися вершкове, шоколадне, фруктове, молочне морозиво. Відпускалося воно у вафельних стаканчиках вагою по Іоо г. Виробничі процеси були частково автоматизованими, натомість зважування й розфасовка у стаканчики проводилися вручну ${ }^{86}$. Молококомбінат № I у рік виготовляв 380 т морозива ${ }^{87}$. Із середини 1950-х рр. якість продукції львівських підприємств суттєво зросла, вона заслужено посіла достойне місце серед молочних десертів мешканців.

Простим і водночас дуже калорійним продуктом повоєнного раціону львів'ян були яйця. Для прикладу, у ресторані «Інтурист» у грудні 1944 р. у зв’язку з продовольчими труднощами як основну страву подавали яйця з бурячками ${ }^{88}$. Утім у меню львівських ресторанів вони були радше винятком, натомість в їдальнях і чайних довгий час залишалися важливою стравою. Зважаючи на це, попит на яйця зберігався на стабільно високому рівні. Основними постачальниками цього продукту, поряд із птахокомбінатом та сільськогосподарськими артілями, було населення довколишніх сіл. Селяни продавали яйця на базарі, а також пропонували адресну доставку на довготривалій основі. Це було вигідно як самим мешканцям села (уникали спекулянтських мереж), так і міста (кращий контроль придбаного) ${ }^{89}$. 92-річний С.Гіренко про реалії життя у Львові в 1946-I950 рр. згадував: «Багато селянок із довколишніх сіл приносили львів'янам продукти, переважно молоко, яйця. Носили їх за плечима в таких клунках, тому цих жінок називали “парашутистами”» ${ }^{\circ}$. Ціна на яйця залежала від сезону та виробника, а продавали їх переважно десятками або «копами».

\footnotetext{
${ }_{82}$ Там само. - Спр.274. - Арк.42.

83 Там само. - Спр.237. - Арк.9.

${ }^{84}$ Вільна Україна. - 1949. - 25 червня.

85 Львовская правда. - 1951. - 30 марта.

${ }^{86}$ Вільна Україна. - 1953. - 19 серпня.

${ }_{87}$ ДАЛО. - Ф.Р-6. - Оп.2. - Спр.400. - Арк.51-53.

${ }^{88}$ Gansiniec R. Notatki Lwowskie (1944-1946). - Wrocław, 1995. - S.17.

${ }_{89}$ ДАЛО. - Ф.Р-6. - Оп.2. - Спр.559. - Арк.78.

${ }^{9}$ Вийшли із ЗАГСу і на радощах з ’їли по два качани кукурудзи...: Подружжя Гіренків згадує Львів перших повоєнних років // Леополіс: Безкоштовний додаток для львів'ян від газети «Високий Замок» (Львів). - 2012. - 1 березня.
} 
У жовтні 1944 р. десяток базарних яєць можна було придбати за 60 руб. ${ }^{\text {г }}$ Після скасування карткової системи та проведення грошової реформи у січні 1947 р. ринкова ціна знизилася до 25-28 руб. ${ }^{92}$, а десяток державних коштував го-І4 руб. ${ }^{93}$ Споживали містяни в основному курячі яйця, хоча на початку І95о-х рр. у раціоні львів’ян дещо зросла питома вага качиних.

Згідно з державним стандартом, яйця поділялися на категорії: дієтичні (двох гатунків - добірні та звичайні), свіжі (першого - третього гатунків), холодильникові та вапновані. Гатунок визначався на основі ваги го яєць. Зокрема десяток дієтичних добірного гатунку мав важити 6оо г, звичайних - 510 г, свіжих першого гатунку - 500 г, другого - 430 г, третього - 4Іо г. Усі яйця мали бути чистими. «Холодильниковими» називали ті, які понад г міс. перебували у холодильнику, а «вапнованими» - котрі зберігалися у вапняному розчині. Вагові вимоги до перших і других були такими ж, як і до яєць категорії «свіжі». За технологією вапнування яйця зберігалися у великих басейнах або чанах, наповнених гашеним вапном, яке утворювало на поверхні так званий «льодок» - плівку з вуглекислого кальцію, що виконувала функцію антисептика. У такому розчині яйця можна було тримати до 8 міс. Після вапнування вони мали дещо тоншу, шершаву шкаралупу й легкий присмак вапна. Станом на вересень 1944 р. заготівельне управління Львівської облспоживспілки відало резервуарами на вул. Кульпарківській, 64-66 (яйцебаза)ำ, Медовій, 7 (2 басейни), Паненській, 22 (2), пл. Теодора, 8 (2), Валовій, II (3), Сніжній, 5 (I)95, Ваговій, ІІ (3), Соняшній, І2 (2 басейни $)^{96}$. Із поширенням холодильного обладнання вапнування застосовувалося дедалі рідше.

Підсумовуючи, наголосимо, що попри невелику частку аграрного сектору у загальноміській економіці, внесок його в бюджет Львова другої половини 1940 - початку 1950-х рр. був більш ніж відчутним. Позаяк одна лише артіль ім. І-го Травня давала місту мільйонні прибутки, забезпечувала місцеві м’ясокомбінати й молокозаводи сировиною, створюючи тим самим замкнений цикл постачання та виробництва м’ясо-молочної, сільськогосподарської продукції. Серед продовольства, виготовленого на базі сировини міських господарств, особливою популярністю користувалися варені й напівкопчені ковбаси. Молочні товари львівських підприємств займали незначний відсоток у загальному обсязі споживання молока в місті. Забезпечувалися лише найбільш затребувані сфери - дитяче харчування та лікарні. Причина полягала в недостатньому розвитку тваринництва в підсобних господарствах, артілях Львова. Асортимент молочних товарів був доволі широким - від традиційного молока жирністю 3,2\%, сиру, морозива до молока з домішками та дитячих сумішей і відварів. На початку І95о-х рр. випуск молочної продукції потроху почав наростати. Дефіцит продовольства в перші повоєнні роки призводив подекуди до метаморфоз, часто виводячи на перше місце у споживчому раціоні продукти, які раніше слугували перекусом або використовувалися при готуванні основних страв. Безсумнівну першість у цій категорії утримували яйця - відносно дешевий і доступний продукт із хорошими смаковими та калорійними властивостями. Вони стали буденністю не лише у львівських закладах громадського харчування, але й у деяких ресторанах. Проте відсутність холодильного обладнання робила цей продукт недовговічним. Доступні

\footnotetext{
${ }^{91}$ ДАЛО. - Ф.Р-100. - Оп.1. - Спр.4. - Арк.19-21; Спр.12. - Арк.85.

${ }_{2}$ Там само. - Ф.Р-6. - Оп.2. - Спр.233. - Арк.5-6.

${ }_{33}$ Вільна Україна. - 1947. - 15 грудня.

94 ДАЛО. - Ф.Р-6. - Оп.2. - Спр.7. - Арк.238.

${ }_{95}$ Там само. - Арк.207.

${ }^{6}$ Там само. - Спр.34а. - Арк.360.
} 
на той час методи збереження - вапнування, парафінування - не були досконалими і частково спричиняли псування яєць.

У цілому, можемо констатувати, що в перші повоєнні роки традиційна економіка Львова співіснувала в одному просторі з сільськими практиками у вигляді сільгоспартілей, підсобних та індивідуальних господарств. Система зайнятості у сільському господарстві добре корелювала з партійною політикою репрезентації класовості в усіх сферах міського життя. Підсобні господарства, артілі, відгодівельні комплекси, організовані в умовах харчового дефіциту як один з елементів виживання, були нетиповим явищем повоєнного міста. Водночас, розводячи худобу, вирощуючи овочі та фрукти, мешканці не тільки забезпечували собі додатковий раціон, але й формували своєрідне соціальне середовище Львова, яке відрізнялося від типових урбанізаційних процесів інших міст.

\title{
REFERENCES
}

1. Gansiniec, R. (1995). Notatki Lwowskie (1944-1946). Wrocław. [in Polish].

2. Gil, S.A., Shafershtejn, S.Ya. (1952). Pitatelnye smesi dlya detej grudnogo vozrasta. Kiev. [in Russian].

3. Herbilskyi, H. (Ed.) (1956). Istoriia Lvova: Korotkyi narys. Lviv. [in Ukrainian].

4. Inikhov, H.S., Speranskyi, V.H., Pysariev, N.S., Syrevych, A.V., Bakzevych, D.D. (1954). Tovaroznavstvo kharchovykh produktiv. Kyiv. [in Ukrainian].

5. Isaievych, Ya. (Ed.) (2007). Istoriza Lvova, 3: Lystopad 1918 - poch. XXI st. Lviv. [in Ukrainian].

6. Kyselova, V.B. (1955). Dytiacha kukhnia: Knyha dlia materiv pro prybotovliannia yizhi ditiam. Kyiv. [in Ukrainian].

7. Molchanov, O.P., Lobanov, D.I., Lifshits, M.O., Tsyplenkov, N.P. (Eds.) (1952). Kniga o vkusnoj i zdorovoj pishche. Moskva. [in Russian].

8. Sekretariuk, V.V. (Ed.) (1984). Istoriia Lvova. Kyiv. [in Ukrainian].

\author{
Roman HENEHA \\ Candidate of Historical Sciences (Ph. D. in History), \\ Docent at Department of Historical Local History, \\ I.Franko National University of Lviv \\ (Lviv, Ukraine), r_genega@yahoo.com \\ ORCID: https://orcid.org/oooo-0oo2-0346-405X
}

\section{Iryna PANCHUK}

Doctor of Philosophy Sciences (Dr. Hab. in Philosophy), Docent,

Professor at Department of Philosophy,

Rivne State University of Humanities

(Rivne, Ukraine), irinapanchuk2I@gmail.com

ORCID: https://orcid.org/oooo-oooI-630I-4280

\section{"Rural in the City": Lviv's Agricultural Sector and Its Contribution to the City's Postwar Economy}

\begin{abstract}
The purpose of the study is to shed light on the interesting phenomenon of post-war Lviv in $1940^{\mathrm{s}}$ and $1950^{\text {s, }}$, which is interaction between the city and the village within the Lviv city space. Rural and urban practices that coexisted in one area of post-war Lviv had a serious impact on the daily life of the city, changed its cuisine and ethnic color. The author uses general scientific methods - causal, comparative and systematic approaches and other. Scientific novelty. For the first time, the activities of agricultural enterprises that actively used the land within the city are covered. A separate aspect, being analyzed, is the production of local food enterprises and their
\end{abstract}


popularity among the citizens. The author also determined the level of providing the population with food. The article demonstrates the methods of preserving food in the time of the absence of refrigeration equipment. It has been proved that agrarian experiments in the city were rather exceptional and caused by post-war disturbances. As a result of the cooperation between the city and the village, a twofold social environment was conducted in Lviv, with peculiar impact on the post-war city. Conclusions. In the first post-war years, the traditional farms of post-war Lviv coexisted with rural practices that were expressed in the cultivation of agricultural units, utility and individual farms. The employment system in agriculture correlated well with the party's policy of class representation in all spheres of urban life. Ancillary farms, agricultural unions and feeding complexes, organized under conditions of food shortage as one of the elements of post-war survival were not typical phenomena of the post-war city. The author states that despite the small size of Lviv agricultural sector, its contribution to the city-wide financial system was more tangible. Only one collective farm named May, 1, gave the city large profits, not to mention less successful unions and farms. An important aspect of its operations was the provision of raw materials for local meat-packing plants and dairies, thus creating a closed cycle of food supply in Lviv. The supplies of Lviv dairies were a small part of the total milk consumption in the city. At the same time, by raising animals and growing vegetables and fruits, Lviv citizens not only provided themselves with an additional cuisines, but also formed a kind of social environment of post-war Lviv that differed from the typical urbanization processes of other cities.

Keywords: Lviv, artel, collective farm, subsidiary farm, food products. 